\title{
The review of the patterns of presentation and various prognostic factors in male breast cancer patients
}

\author{
Dillip Kumar Parida, Navneet Singh Majhail, Goura Kishore Rath, Pramod Kumar Julka
}

\begin{abstract}
Abstrak
Tujuan studi ini adalah untuk mempelajari tampilan, gejala, berbagai faktor prognostik dan modalitas terapi dalam penatalaksanaan kanker payudara pada pria. Tiga puluh kasus kanker payudara pria telah diobati dengan radioterapi di bagian kami antara tahun 1983-1997. Semua penderita selain pembedahan, mendapat radioterapi (26) dan kemoterapi (12). Mastektomi radikal dilakukan pada 18 penderita, sedangkan 6 penderita menjalani mastektomi radikal yang dimodifikasi dan 2 pasien dengan mastektomi biasa. Radioterapi pascabedah diberikan dengan dosis 50 Gy dalam 25 fraksi selama lima minggu. Kemoterapi diberikan sebagai ajuvan. Selain itu semua pasien juga mendapat terapi hormonal. Empat pasien hilang dari follow-up. Follow-up dilakukan selama $10-92$ bulan dengan median 38 bulan. Angka bebas penyakit 2 dan 5 tahun berturut-turut adalah 87,7 dan 54,67\%. Satu pasien mengalami kekambuhan lokal, sementara 5 pasien mengalami metastasis. Usia, status kelenjar limfe dan metastasis merupakan faktor prediktor yang penting. Saat ini, umumnya kanker payudara pria diobati seperti kanker payudara wanita sesuai dengan stadium masingmasing. Diperlukan studi acak yang lebih besar untuk optimalisasi pendekatan terapi. (Med J Indones 2001; 10: 84-7)
\end{abstract}

\begin{abstract}
This study was aimed to analyze the patterns of presentation, various prognostic factors and therapeutic modalities for the management of breast cancer in male patients. Thirty cases of male breast cancer were treated with radiotherapy at our department between 1983 and 1997. All the patients were treated with radiotherapy besides surgery (26) and chemotherapy (12). Radical mastectomy was performed in 18 patients, while 6 patients were treated with modified radical mastectomy and 2 patients with simple mastectomy. The post operative radiotherapy was applied at the dose of 50 Gy in 25 fractions over a period of five weeks. The chemotherapy was administered in an adjuvant setting. All the patients were received hormonal therapy. Four patients were lost to follow up. The follow up period ranged from 10-92 months with a median of 38 months. The disease-free survival at 2 and 5 years were $87.7 \%$ and $54.67 \%$, respectively. One patient recurred locally, whereas 5 patients had distant metastasis. The age, lymph node status at presentation and presence of distant metastasis were the important prognostic factors. At present, the trend is to treat male breast cancer patients like those of females stage per stage. More randomized studies are required for optimizing therapeutic approach. (Med J Indones 2001; 10: 84-7)
\end{abstract}

Keywords: male breast cancer, radiotherapy, chemotherapy, surgery

The incidence of male breast cancer is less common than those of females. It forms less than $1 \%$ of all the cases seen at most of the centers. The age adjusted incidence rates are 0.3 per 100,00 population according to 1989 Delhi \& Mumbai cancer registries, while female breast cancer tops the list of female malignancies in both registries. ${ }^{1}$ The 1995 Delhi cancer registry shows a definite increasing trend in the crude and age adjusted rate of male breast cancer $(0.4$ and 0.7 respectively), while that of female breast cancer are 18.3 and 27.7, respectively. Because of the low incidence of male breast cancer and lack of

Department of Radiation Oncology, All India Institute of Medical Sciences, New Delhi, India 110029 clinical trials there are no definite guidelines exist as to achieve optimum therapeutic result. But the trend worldwide is to manage like a female breast cancer.

\section{METHODS}

This analysis was carried out at the Department of Radiation Oncology, All India Institute of Medical Sciences, New Delhi, a tertiary cancer care hospital of India. The study period ranged from 1983 till 1997 during which 30 patients were managed with multimodal approach. The records of these patients were studied for their presenting symptoms, diagnostic procedures used, stage at presentation, mode of treatment received and pattern of follow up. Actuarial, 
overall and disease-free survival analysis and univariate analysis of prognostic factors were carried out.

\section{RESULTS}

Age range was between $40-70$ years with the median of 60 years. The majority of patients (23/30) were in the range of 40-70 years. The duration of symptoms ranged from 1-36 months (averaged 6 months). Breast lump was present in all patients besides pain (17), nipple discharge (8), retraction of nipple, ulceration (6) and peau d'orange (3). The lump was present in the upper outer quadrant (14), upper inner quadrant (8) and central mass (8). The size of the tumor varied from 0.5 to $8 \mathrm{~cm}$. Palpable lymphadenopathy at presentation was found in 18 patients out of which 16 had axillary nodes and 2 with supra clavicular as well as axillary nodes.

No patient had any family history of breast cancer, previous exposed to radiation, estrogenic drug intake, orchidectomy or Klinefelters syndrome. Gynaecomastia was found on examination in 6 of the 30 patients. Besides routine haematological evaluations all these patients had fine needle aspiration cytology (FNAC) and histopathological study of the surgicopathological specimen for confirmation of diagnosis. In all the cases FNAC had shown positive diagnosis which later on was corroborated by the histopathological findings. The common surgical procedure was radical mastectomy which was performed in 18 cases while 6 had modified radical mastectomy, and 2 had simple mastectomy. Four patients did not had any surgery. Infiltrating duct carcinoma was the most common histological type followed by intralobular variety. The over all TNM status is described in detail in table 1. Most of the tumors presented in advanced stage (20/30). The commonest pattern of failure was the distant metasiasis which is elaborated in table 2. One patient recurred locally. All the patients received adjuvant hormonal treatment. However 12 patients had combination chemotherapy. The chemotherapy regimens consisted of cyclophos-phamide, methotraxate, $5 \mathrm{FU}$, epirubicin, paclitaxel, docetaxel either single or vaious combinations. Seven patients received $\mathrm{CMF}, 5$ received $\mathrm{CEF}$, paclitaxel in 3 and docetaxel in 2 patients. The second line chemotherapy was administered in 10 out of 12 patients who failed to the first line chemotherapy. Twenty four patients received radical loco-regional radiation therapy while the rest were treated palliatively. The institute protocol of post operative radiotherapy is to deliver $50 \mathrm{~Gy}$ in 25 fractions over a period of five weeks. The radiation planning is done under a simulator and the treatment is executed by either a tele-cobalt or high energy linear accelerator after 3 weeks of surgery. Patients having symptomatic metastasis were managed with palliative radiation therapy and combination chemohormonal therapy.

Table 1. TNM stage distribution of the patients

\begin{tabular}{ccccc}
\hline & Nx & N1 & N2 & N3 \\
\hline Tx & 0 & 4 & 1 & 0 \\
T1 & 0 & 1 & 2 & 0 \\
T2 & 0 & 3 & 3 & 1 \\
T3 & 0 & 1 & 0 & 0 \\
T4 & 0 & 3 & 6 & 5 \\
\hline
\end{tabular}

Table 2. Patient profile

Total no patients analysed : 30

\begin{tabular}{|c|c|c|}
\hline \multicolumn{3}{|l|}{ Age distribution: } \\
\hline$<40$ years : & \multicolumn{2}{|c|}{$: 3$} \\
\hline $40-50$ years & \multicolumn{2}{|c|}{$: 4$} \\
\hline $50-60$ years & \multicolumn{2}{|c|}{9} \\
\hline $50-60$ years & \multicolumn{2}{|c|}{10} \\
\hline$>70$ years & \multicolumn{2}{|c|}{$: 4$} \\
\hline \multicolumn{3}{|l|}{ Symptoms: } \\
\hline \multirow{2}{*}{ Painless lump $: 17$} & \multicolumn{2}{|c|}{$: 17$} \\
\hline & \multicolumn{2}{|c|}{$: 8$} \\
\hline \multicolumn{3}{|c|}{ Retracted nipple : 8} \\
\hline \multicolumn{3}{|c|}{ Retracted nipple : 8} \\
\hline Ulceration : & \multicolumn{2}{|c|}{$: 6$} \\
\hline Pe-u-de orange : & \multicolumn{2}{|c|}{$: 3$} \\
\hline \multicolumn{3}{|l|}{ Surgery : } \\
\hline \multicolumn{2}{|c|}{ Simple mastectomy } & $: 2$ \\
\hline \multicolumn{2}{|c|}{ Modified radical mastectomy } & $: 6$ \\
\hline \multicolumn{2}{|c|}{ Radical mastectomy } & $: 18$ \\
\hline \multicolumn{3}{|c|}{ Radiotherapy (post-op): } \\
\hline \multicolumn{2}{|l|}{ Chest wall only } & $: 6$ \\
\hline \multicolumn{2}{|c|}{ Chest wall + SCF + Axilla } & $: 3$ \\
\hline \multicolumn{3}{|c|}{ Chest wall + SCF + Axilla + IMC : 15} \\
\hline \multicolumn{3}{|l|}{ Failure pattem : } \\
\hline Locally & $: 1$ & \\
\hline Locally + Distant & $: 2$ & \\
\hline Distant only & $: 3$ & \\
\hline
\end{tabular}

IMC : Internal mammary chain, SCF : Supraclavicular fossa

The follow up period ranged from 10-92 months with a median of 38 months. Four patients were lost to follow up. The axillary lymph node status, presence of distant metastasis at presentation and age were the 
important prognostic factors found to affect the actuarial disease free survival.

\section{DISCUSSION}

The oldest patient in our series was of 79 years old. The mean age at presentation in men has been found to be 6-11 years more than women. The mean age of the female patients suffering from breast cancer coming to our centre was 46.8 years with the range of 22-70 years. Scheike et $\mathrm{al}^{2}$ have reported that gynaecomastia, either clinical or microscopic is often associated with male breast cancer. But till today no definite correlation has been established between them. Olsson \& Ranstam ${ }^{3}$ have tried to corelate history of head injury and development of breast cancer in male. We have recorded this history in eleven (36\%) patients. The higher incidence in the left breast than right is usually observed but the cause is very difficult to establish. We had 14 left breast cancers cases vs 16 right breast tumors in our series. Many studies report that painless breast lump is the usual presenting feature which was observed in our analysis. ${ }^{4,5}$ Most of the patients (14) presented with T4 lesions showing that the tumor in male very quickly involves the skin even if the $\mathrm{T}$ size is small. It is already documented that males present in a late stage than females. Borgen et $\mathrm{al}^{6}$ have reported the incidence of early breast in male patients can go up to the tune of $77 \%$.

Surgery remains the mainstay modality of treatment. Radical mastectomy (RM) is the commonest procedure at our institution. However modified radical mastectomy (MRM) is commonly practiced in western countries. Radiation therapy is the principal adjuvant modality besides chemo and hormonal therapy. Post operative radiation therapy has definitely improved the loco-regional recurrence rate and ultimately disease free survival. ${ }^{4,7}$ In our series all the patients received radiation therapy (24-post-op, 6Palliative). Crichlow \& Galt ${ }^{4}$ have recommended that the internal mammary chain should be treated in all cases, as the tumors are mostly centrally located resulting a high chance of their involvement. Only one patient recurred locally in our series.

Chemo and hormone therapy is used in node positive cases. In our series all the patients received hormonal therapy in the form of tamoxifen. However the relative role of tamoxifen have not been defined. Ribeiro \& Swindell ${ }^{8}$ have shown a significant survival advantage in the patients treated with tamoxifen. Many studies have also shown a benefit in over all as well as disease free survival in the patients received adjuvant chemotherapy. ${ }^{6,9}$ Receptor status is also an important predictor of hormonal therapy, which play a greater role in case of node positive patients.

As in our center, majority of patients presents in an advanced stage, neo adjuvant therapy may have a significant role in the management. Eight patients received neo adjuvant chemotherapy. The disease free survival rates at 2 years and 5 years were $87.7 \%$ \& $54.6 \%$. Borgen et $\mathrm{al}^{6}$ reported 5 years over all \& DFS of $85 \%$ \& $68 \%$ respectively. Whereas Engin and $\mathrm{Unsal}^{10}$ reported a 5 year overall \& DFS of $37 \& 27 \%$ respectively. In a collective review, Crichlow ${ }^{5}$ has reported a 5 year overall survival rate of $49 \%$. The outcome of male breast cancer is improving over a period of time with availability of newer chemotherapeutic agents, quicker diagnosis and above all, increased sense of awareness on the part of patients. On univariate analysis, the age at presentation, axillary lymphnode status and presence of distant metastasis at presentation were found to influence the DFS significantly in our series. Many literatures show axillary nodes as the single most important prognostic factor in case of male breast cancer. ${ }^{5,11}$ A relationship with the number of positive nodes DFS has also been reported by Guinee et al. ${ }^{12}$ In our study the node negative patients faired better as regards to the survival (med DFS 57 mo) than node positive patients (med DFS $48 \mathrm{mo}$ ). Adami et $\mathrm{al}^{11}$ have reported the adverse effect of age on the overall outcome. Engin \& Unsal ${ }^{10}$ have also found that when the patient is more than 60 years of age the prognosis is bad when compared to the patients of less than 60 years. In our series, patients below 50 years of age had a shorter DFS.

In India, unlike female patients with breast cancer, male patients usually present in an advanced stage which influence tha treatment policies. The mean age for these patients is about 10 years less than the patients in west. Stage for stage, the current management of male breast cancer in generally similar to that of female breast cancer except breast cancer conservation.

\section{REFERENCES}

1. Biennial report 1988-89. National Cancer Registry Programme of the Indian Council of Medical Research, New Delhi 1992, p 88-128. 
2. Scheike O, Visfeld J. Male breast cancer; Gynaecomastia in patients with breast cancer. Acta Pathol Microbiol Scand 1973; 81:359-65.

3. Olsson H, Ranstam J. Head trauma and exposure to prolactin elevating drugs as risk factors for male breast cancer. J Natl Cancer Inst 1988; 80:679-83.

4. Crichow RW, Galt SW. Male breast cancer. Surg Clin North Am, 1990; 70: 1165-77.

5. Crichow RW. Carcinoma of the male breast. Surg Gynecol Obstet 1972; 134:1019.

6. Borgen PI, Wong GY, Vlamis V et al. Current management of male breast cancer. A review of 104 cases. Ann Surg 1992; 215:451-9.

7. Patel HZ, Buzdar AU, Hortobagyi GN. Role of adjuvant therapy in male breast cancer. Cancer 1989; 64:1583-5.
8. Ribeiro G, Swindell R. Adjuvant tamoxifen for male breast cancer (MBC). Br J Cancer 1992; 65:252-4.

9. Bagley CS, Wesle MN, Young RC, Lippman ME. Adjuvant chemotherapy in males with cancer of the breast. Am J Clin Oncol 1987; 10:55-60.

10. Engin K, Unsal M. Cancer of the male breast. The Turkish experience. J surg Oncol 1993; 53:128-32.

11. Adami HO, Hakulinen $\mathrm{T}$, Ewertz $\mathrm{M}$ et al. The survival pattern in male breast cancer. An analysis of 1429 patients from the Nordic countries. Cancer 1989; 64:1177-82.

12. Guinee VF, Olsson H, Moller $\mathbf{T}$ et al. The prognosis of breast cancer in males. A report of 335 cases. Cancer 1993; 71:154-61. 